\title{
A growth hormone-based phylogenetic analysis of euteleostean fishes including a representative species of the Atheriniformes Order, Odontesthes argentinensis
}

\author{
Luis F. Marins ${ }^{1}$, Jose A. Levy ${ }^{1}$, Josep M. Folch ${ }^{2}$ and Armand Sanchez ${ }^{2}$ \\ ${ }^{1}$ Fundação Universidade Federal de Rio Grande, Departamento de Química, \\ Núcleo de Biologia Molecular, Laboratório de Bioquímica Marinha, Rio Grande, RS, Brazil. \\ ${ }^{2}$ Universitat Autònoma de Barcelona, Facultat de Veterinària, Unitat de Genética, Bellaterra, \\ Barcelona, Spain.
}

\begin{abstract}
The GH (growth hormone) cDNA sequence of the marine silverside fish Odontesthes argentinensis was obtained using the RACE protocol (Rapid Amplification of cDNA Ends). The marine silverside GH cDNA sequence is 928 nucleotides long and was found to encode a polypeptide of 204 amino acids, including a signal peptide of 17 amino acids. The 5' and 3' untranslated regions of the messenger are 109 and 204 nucleotides long, respectively. The deduced $\mathrm{GH}$ amino acid sequence was used to infer a phylogenetic tree with $\mathrm{GH}$ amino acid sequences from representative species belonging to the Euteleostei Subdivision using the maximum parsimony method. The topology found is according to the major phylogenetic grouping of euteleosts. The results corroborate the hypothesis that atherinids are not related to paracanthopterygians as previously suggested, and show a lack of solid synapomorphies among most of the Acanthopterygii Orders analysed indicating a complex assemblage of fishes in which the phylogenetic tree remains indeterminable.
\end{abstract}

Key words: growth hormone, cDNA, RACE (Rapid Amplification of cDNA Ends), phylogeny.

Received: April 17, 2003; Accepted: February 27, 2003.

\section{Introduction}

Molecular data have been used recently as a source of information to elucidate phylogenetic history of fish groups using mitochondrial DNA and nuclear ribosomal sequences associated with morphological observations (Wiley et al., 2000). However, more appropriate nuclear genes may provide molecular data for more expressive phylogenetic reconstruction, since they meet several criteria to be used in this kind of analysis including (i) enough conservation of the sequence avoiding saturation; (ii) sufficient length; and (iii) minimal amount of homoplasy. The growth hormone $(\mathrm{GH})$ gene meets these requirements and it has produced fish phylogenies with substantial statistical confidence (Bernardi et al., 1993; Rubin and Dores, 1994, 1995; Venkatesh and Brenner, 1997). This hormone is a polypeptide of fundamental importance for growth regulation in vertebrates and, together with prolactin and somatolactin, constitutes a family of pituitary hormones with similar structure and function that appear to have originated from a common ancestral gene before the evolution of fishes (Kawauchi and Yasuda, 1989).

Send correspondence to J.A.L. E-mail: levy@mikrus.com.br.
A number of different forms of the GH gene are present in several vertebrate species and gene duplication and divergence or mutation and allelic variation are believed to be responsible for these, in an evolutionary scenario of near-stasis periods interrupted by sustained bursts of rapid change (Wallis, 1996). In order to understand the molecular phylogeny of the GH, many efforts have been concentrated on the characterisation of GHs in fishes. Within the Euteleostei Subdivision, the GH amino acid sequence has already been determined in species in the Ostariophysi (Cypriniformes and Siluriformes Orders), Protacanthopterygii (Salmoniformes Order), Paracanthopterygii (Gadiformes Order) and Acanthopterygii (Scorpaeniformes, Perciformes, Pleuronectiformes and Tetraodontiformes Orders) Superorders. In contrast, no information about the GH gene or its amino acid sequence has been reported in atherinids.

The marine silverside fish, Odontesthes argentinensis, belongs to the Atheriniformes Order, Atherinopsidae Family, consisting of fishes distributed in inland, estuarine and oceanic waters world-wide with a large number of genera and species. Although most silversides are annual, small-sized and forage fishes, some 
species are commercially important in South America and have been used for stocking and intensive cultivation in several countries such as France, Israel, Italy and Japan where they are considered a promising alternative to commonly reared fishes in aquaculture. Recent molecular studies on this fish group have been carried out at populational level based on allozyme markers (Beheregaray and Levy, 2000).

In this paper, we report the isolation and characterisation of the GH cDNA from a marine teleost representing the Atheriniformes Order, using the RACE protocol (Rapid Amplification of cDNA Ends, Frohman et al., 1988). The deduced amino acid sequence of the msGH cDNA was used to perform a phylogenetic analysis to investigate the relationship of this sequence with other euteleostean $\mathrm{GH}$ sequences available.

\section{Material and Methods}

The alignment of several known acanthopterygian GH amino acid sequences allowed us to identify a conserved amino acid sequence at the $\mathrm{C}$ terminus region. This region was fairly conserved in all sequences compared at nucleotide level (data not shown). It was used to design a forward degenerate gene specific primer (GSP1: 5'- TTC AA(GA) AA(GA) GAC ATG CA - 3') to obtain the cDNA from this point of the transcript to the $3^{\prime}$ end, using RT-PCR (Reverse Transcriptase-PCR). This reaction was carried out according to the 3' RACE System protocol (Gibco BRL). Total RNA was isolated from approximately $100 \mathrm{mg}$ of pituitaries using Trizol Reagent (Gibco BRL) according to the manufacturer's protocols and used as a template for oligo (dT)-primed cDNA using the AP primer (5'GGC CAC GCG TCG ACT AGT AC (T)17 - 3', Gibco BRL). The first strand msGH cDNA was then used as a template in a PCR with the primers GSP1 and AUAP (5'GGC CAC GCG TCG ACT AGT AC - 3', Gibco BRL). Once the 3' end sequence was known, a reverse gene specific primer was designed (GSP2: 5' - ATT TAG CCA CCG TCA GGT AGG TCT TAC - 3') and used for the 5' end PCR amplification with the primer AAP (5'- GGC CAC GCG TCG ACT AGT ACG GGI IGG GII GGG IIG - 3') from the 5' RACE System (Gibco BRL) according to the manufacturer's protocol. Both PCR products ( 3 ' and $5^{\prime}$ ' end fragments) were cloned in a T-vector and sequenced completely (automatic sequencing), and the amino acid sequence deduced (Figure 1).

Several GHs, including the marine silverside, were aligned using CLUSTAL X (Thompson et al., 1997) and the resulting alignment refined by introducing gaps to maximise the homology and maintain GHs structural information as suggested by Rubin and Dores (1995). The eel $A$. japonica (Teleostei, Anguilliformes) was used as outgroup. The phylogenetic analysis was performed using the Phylogeny Inference Package PHYLYP 3.6 (Felsenstein, 1993). The aligned amino acid sequences (Figure 2) were used to perform a phylogenetic analysis using the maximum parsimony method (PROTPARS, for details see PHYLYP 3.6 manual). A bootstrapping analysis using 1000 iterations was performed using SEQBOOT, and only groups that had bootstrap probability values (BP) $>50 \%$ were retained. Significance was assumed when the bootstrap value was $>95$ (Felsenstein, 1985).

\section{Results and Discussion}

The amplification products did not demonstrate any sequence heterogeneity supporting the existence of two msGHs, as has been found in Tilapia nilotica (Ber and Daniel, 1993). The msGH cDNA contains an open reading frame of 615 nucleotides starting at the first ATG codon located at 109 nucleotides from the 5' terminus of the mRNA and ending with a TGA stop codon, encoding a preprotein of 204 amino acids residues as shown in the Figure 1. The msGH mRNA 3' untranslated region is 204 nucleotides long and it contains two polyadenylation consensus sequences AATAAA.

This is the first time an atherinid growth hormone-encoding cDNA has been reported and the deduced amino acid sequence obtained. In addition, no data is available regarding the amino acid sequence of the authentic msGH polypeptide. Since the first 17 amino acid residues from the $\mathrm{N}$ terminus are highly hydrophobic $(70 \%$ of the amino acids residues of this region are non-polar) and also have a high degree of homology to the signal peptide of other fish GHs, it is assumed that in the msGH this region probably represents the signal peptide of the pre-GH which is cleaved upon hormone secretion.

The hormone exhibits typical GH features, such as four cysteine residues, capable of forming two disulphide bonds that are assumed to contribute to the tertiary structure of the hormone molecule, a single tryptophan residue and stretches of amino acids highly conserved in all known GHs. There is only one Asn-Xaa-Thr motif in the msfGH aa sequence $\left(\mathrm{Asn}^{201}\right)$ which is a potential site for $\mathrm{N}$-linked glycosylation. The mature form of msGH deduced from the msGH cDNA sequence contains 187 amino acids, starting with a glutamine. The amino acid sequence, when compared to those of mature GHs from other acanthopterygian fishes, showed higher levels of homology to fish GHs representing the order Perciformes: with a similarity of up to 92\% (data not shown).

The consensus phylogenetic tree obtained (majority rule - Figure 3) showed the major phylogenetic grouping of euteleosts supporting the present classification (Nelson, 1994). Members of the Ostariophysi (I. Punctatus, H. nobilis and C. carpio), Protacanthopterygii (S. salar and $O$. mykiss) and Paracanthopterygii (G. morhua) Superorders grouped according to the current fish classification. Within Acanthopterygii only Pleuronectiformes (S. senegalensis, $P$. olivaceus and $V$. variegatus) grouped as a monophyletic 
lineage. The remaining orders Atheriniformes $(O$. argentinensis), Scorpaeniformes (S. schlegeli), Tetraodontiformes ( $F$. rubripes) and Perciformes ( $S$. aurata, T. thynnus, T. nilotica, L. calcarifer, S. ocellatus and $M$. saxatilis) did not revel any statistically supported relationship, in spite of the high similarity observed between Perciformes and Atheriniformes GHs at the amino acid sequence level.
Since the atherinomorph classification was created by Rosen (1964), several hypotheses about sister-group and family relationship have been suggested based only on morphological characters. Gosline (1971), pointed out the affinity of this group with members of the former perciform Suborder Mugiloidei, which is currently in the Mugilomorpha Series, Mugiliformes Order (Stiassny, 1990). This author proposed that atherinomorphs and mugiloids are sis-

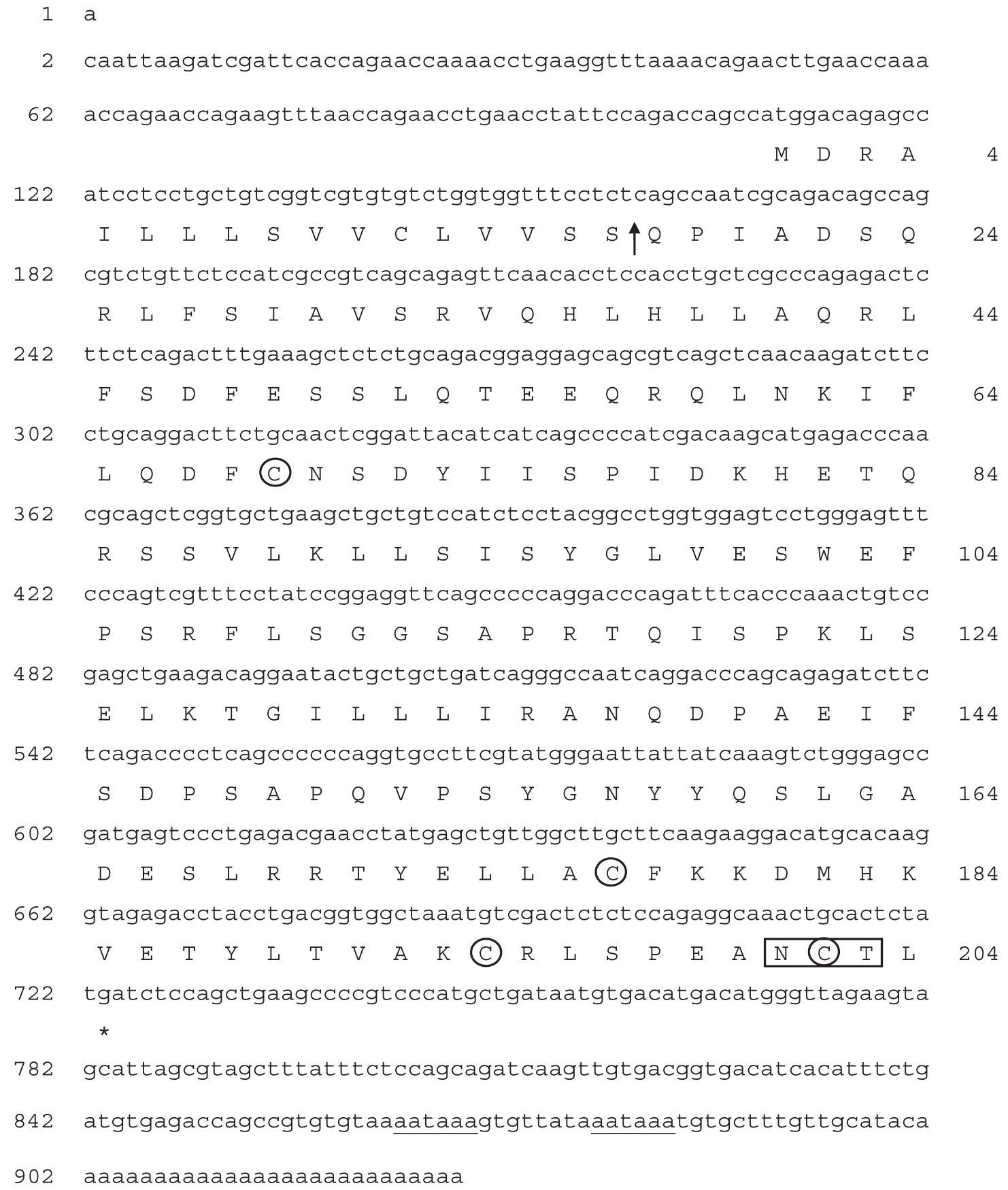

Figure 1 - Complete nucleotide sequence of the marine silverside fish GH cDNA (Genbank acession AF236091) and the deduced amino acid sequence of the hormone. Nucleotides and amino acids are numbered on the left- and right-hand sides, respectively. The arrow indicates the possible site for signal peptide cleavage. The cysteine residues are circled. The asterisk indicates the termination codon. A potential N-glycosylation site (amino acids 201-203) is in the box, and the two polyadenylation signals are underlined. 
L. calcarifer

T.thynnus

T.nilotica

o. argentinensis

s.ocellatus

S. aurata

S.schlegeli

M. saxatilis

V.variegatus

P.olivaceus

S.senegalensis

F.rubripes

G.morhua

S.salar

O.mykiss

C. carpio

H. nobilis

I.punctatus

A. japonica

L. calcarifer

T.thynnus

T.nilotica

O.argentinensis

s.ocellatus

S.aurata

S.schlegeli

M. saxatilis

$V$.variegatus

P.olivaceus

S.senegalensis

F.rubripes

G.morhua

S.salar

o.mykiss

C. carpio

H. nobilis

I.punctatus

A. japonica

L. calcarifer

T.thynnus

T.nilotica

o.argentinensis

s.ocellatus

S.aurata

S.schlegeli

M. saxatilis

V. variegatus

P.olivaceus

S.senegalensis

F.rubripes

G.morhua

S.salar

O.mykiss

C. carpio

H. nobilis

I.punctatus

A. japonica
QPITDSQRLFSIAVSRVQHLHLLAQRRFSEFESSLQTEEQRHVNKIFLQDFCNSDYIISPIDKHETQRSSVLKLLS QPITDSQRLFSIAVSRVQHLHLLAQRLFSDFESSLQTEEQRQLNKIFLQDFCNSDYI ISPIDKHETQRSSVLKLLS QQITDSQRLFSIAVNRVTHLHLLAQRLFSDFESSLQTEEQRQLNKIFLQDFCNSDYI ISPIDKHETQRSSVLKLLS QPIADSQRLFSIAVSRVQHLHLLAQRLFSDFESSLQTEEQRQLNKI FLQDFCNSDYI ISP IDKHETQRSSVLKLLS QPITDSQRLFSIAVSRVQHLHLLAQRLFSDFESSLQTEEQRQLNKI FLQDFCNSDYI ISPIDKHETQRSSVLKLLS QPITDGQRLFSSAVSRVQHLHLLAQRLFSDFESSLQTEEERQLNKI FLQDFCNSDYI ISPIDKHETQRSSVLKLLS QPITDGQRLFSIAVSRVQHLHQVAQRLFFEFESSLQTEEQRQLNKI FLQDYCNSDNI ISPIDKHETQRSS ILKLLS QPITEGQRLFS IAVERVHNLHLLAQRLFTEFESSLQTEEQRQLNKI FLQDFCNSDYI ISPIDKHETQRSSVLKLLS QPITENQRLFSIAVGRVQYLHLVAKKLFSEFENS-QLEDQHPLNKI FLQDFCHSDYFLSPIDKHETQRSSVLKLLS QPITENQRLFSIAVGRVQYLHLVAKKLFSDFENSLQLEDQRLLNKIASKEFCHSDNFLSPIDKHETQGSSVQKLLS QSILD-QRRFSIAVSRVQHIHLLAQKYFSDFESSLQTEDQRQVNKI FLQDFCNSDDI ISPIDKHDTQRSSVLKLLS QPLTDTPRLFSMAVSRVQHLHLLAQRLFADFESSLQTDEQRQLNKKFLP-FCNSDS I IS PNDKHETQRSSVLKLLS HPLIDSQRLFSIAVNRIQHLHMLAERIFSELESSLQIEEQRQLNKI FLPDFCNSDS I ISPIDKHETQRSSVLRLLT - - MENQRLFNIAVNRVQHLHLLAQKMFNDFEGTLLSDERRQLNKI FLLDFCNSDS IVSPIDKQETQKSSVLKLLH - - - IENQRLFNIAVSRVQHLHLLAQKMFNDFDGTLLPDERRQLNKIFLLDFCNSDS IVSPVDKHETQKSSVLKLLH - - - SDNQRLFNNAVIRVQHLHQLAAKMINDFEDSLLPEERRQLSKIFPLSFCNSDYIEAPAGKDETQKSSMLKLLR - - - SENQRLFNNAVIRVQHLHQLAAKMINDFEDNLLPEERRQLSKIFPLSFCNSDS IEAPTGKDETQKSSMLKLLR - - FESQRLFNNAVIRVQHLHQLAAKMMDDFEEALLPEERKQLSKI FPLSFCNSDS IEAPAGKDEAQKSSVLKLLH VEPISLYNLFTSAVNRAQHLHTLAAEIYKEFERS I P PEAHRQLSKTSPLAGCYSDS IPTPTGKDETQEKSDGYLLR

ISYRLVESWEFSSRSLSGG-SA - P- - R- -DQISPKLSELKTGILLLIRANQDGAEMFSDSSALQLAPYGNYYQSLG ISYRLVESWEFPSRSLSGG-SA-P--R- -NQISPKLSELKTGIHLLIRANQDGDEMFADSSALQLAPYGNYYQSLG ISYGLVESWEFPSRSLSGG-SS-L- -R- -NQISPRLSELKTGILLLIRANQDEAENYPDTDTLQHAPYGNYYQSLG ISYGLVESWEFPSRFLSGG-SA-P - R- - TQISPKLSELKTGILLLIRANQDPAEIFSDPSAPQVPSYGNYYQSLG ISYRLVESWEFPSRSLSGG-SA-P--R- -NQISPKLSDLKTGILLLIRANQDGAEI FPDSSTLQLAPYGNYYQSLS ISYRLVESWEFPSRSLSGG-SA - P - R- -NQISPKLSELKTGIHLLIRANEDGAEI FPDSSALQLAPYGNYYQSLG ISYRLVESWEIPSRSLSGG-SA-P--R- -NLISPKLTQLKAGILLLIEANQDGAELFPDSSALQLAPYGNYYQSLG ISYRLIESWEFPSRSLSVG-PA-A--R--NQISPKLSELKTGILLLIGANQDGAEMFPDSSTLQLAPYGNYYQSLG ISYRLIECWEFSSRFL - - - VAGFAER - -AQVTSKLSELKTGLMKLIEANQDGAGGFSESSVIQLTPYGNYYQSVG VSYRLIESWEFFSRFL - - - -VASFAVR - - TQVTSKLSELKMGLLKLIEANQDGAGGFSESSVLQLTPYG - - - - - ISVRLIESWEFSSRFV - - - TWSTFPR - -NQISHKLSELKTGIRMLIEANQDGAEVFSDSSTFQLAPYGNFYQSLG ISYRLIESWDFPSLSLSGG - - - - - - - - LSPKLSDLKTGILLLI KASQDGADMFSESTTLQLGPYENYYQNLG VSYRLIESWEFPSQSLPGG - - SVL-RN- - QISPKLSELKNGIHILIRTSQGAGDALVEADP - -MSPYGGYYQALG ISFRLIESWEYPSQTL- - AISNSLMVRNSNQISEKLSDLKVGINLLI KGSQDGVLSLDDNDSQHLPPYGNYYQNLG ISFRLIESWEYPSQTL - - I ISNSLMVRNANQI SEKLSDLKVGINLLITGNQDGVLSLDDNDSQQLPPYGNYYQNLG ISFHLIESWEFPSQSLSGTVSNSLTVGNPNQLTEKLADLKMGISVLIQACLDGQPNMDDNDS - LPLPFEDFYLTMG ISFRLIESWEFPSQTLSGAVSNSLTVGNPNQITEKLADLKVGISVLIKGCLDGQPNMDDNDS - LPLPFEDFYLTMG TSYRLIESWEFPSR - - - - - - - NLGNPNHISEKLADLKMGIGVLIEGCVDGQTGLDENDS - LAPPFEDFYQTLS ISSALIQSWVYPLKTLSDAFSNSLMFGTSDGIFDKLEDLNKGINELMKVVGDGGIYIEDVRN - - - LRYENFDVHLR

ADESLRRTYELLACFKKDMHKVETYLTVAKCRLSPEANCTL ADESLRRSYELLACFKKDMHKVETYLTVAKCRLSPEANCTL GNESLRQTYELLACFKKDMHKVETYLTVAKCRLSPEANCTL ADESLRRTYELLACFKKDMHKVETYLTVAKCRLSPEANCTL GDESLRRTYELLACFKKDMHKVETYLTVAKCRLSPEANCTL TDESLRRTYELLACFKKDMHKVETYLTVAKCRLSPEANCTL ADESLRRTYELLACFKKDMHKVETYLTVAKCRLSPEANCTL ADESLRRTYELLACFKKDMHKVETYLTVAKCRLSPEANCTL VDESFRLNYELFACFKKDMHKVETYLTVAKCRLSPEANCTL - - - - - NSELFACFKKDMHKVETYLTVAKCRLFPEANCTL GDESLRRNYELLACFKKDMHKVETYLTVAKCRLSPEANCTL GEEPLKRTYELLTCFKKDMHKVETYLTVAKCRLSPEANCTL GDGSLRGSYEMLACFKKDMHKVETYLTVAKCRLSPEDNCTL GDGNIRRNYELLACFKKDMHKVETYLTVAKCRKSLEANCTL GDGNVRRNYELLACFKKDMHKVETYLTVAKCRKSLEANCTL -ENNLRESFRLLACFKKDMHKVETYLRVANCRRSLDSNCTL -ESSLRESFRLLACFKKDMHKVETYLRVANCRRSLDSNCTL - EGNLRKSFRLLSCFKKDMHKVETYLSVAKCRRSLDSNCTL NDAGLMKNYGLLACFKKDMHKVETYLKVTKCRRFVESNCTL

Figure 2 - Comparison of the primary amino acid sequences from various fish GHs. The GH sequences included in this analysis are T. nilotica (Genbank accession AAA49437), L. calcarifer (Genbank accession AAC59692), S. ocellatus (Genbank accession AAC63266), M. saxatilis (Genbank accession AAB34389), T. thynnus (Sato et al., 1988), S. aurata (Funkenstein et al., 1991), S. schlegeli (Genbank accession AAB49492), P. olivaceus (Momota et al., 1988), V. variegatus (Genbank accession AAC36716), S. senegalensis (Genbank accession AAA60372), F. rubripes (Venkatesh and Brenner, 1997), G. morhua (Rand-Weaver et al., 1991), O. mykiss (Rentier-Delrue et al., 1989), S. salar (Johansen et al., 1989), C. carpio (Koren et al., 1989), H. nobilis (Bernardi et al., 1993), I. punctatus (Genbank accession AAC60745) and A. japonica (Saito et al. 1988). 


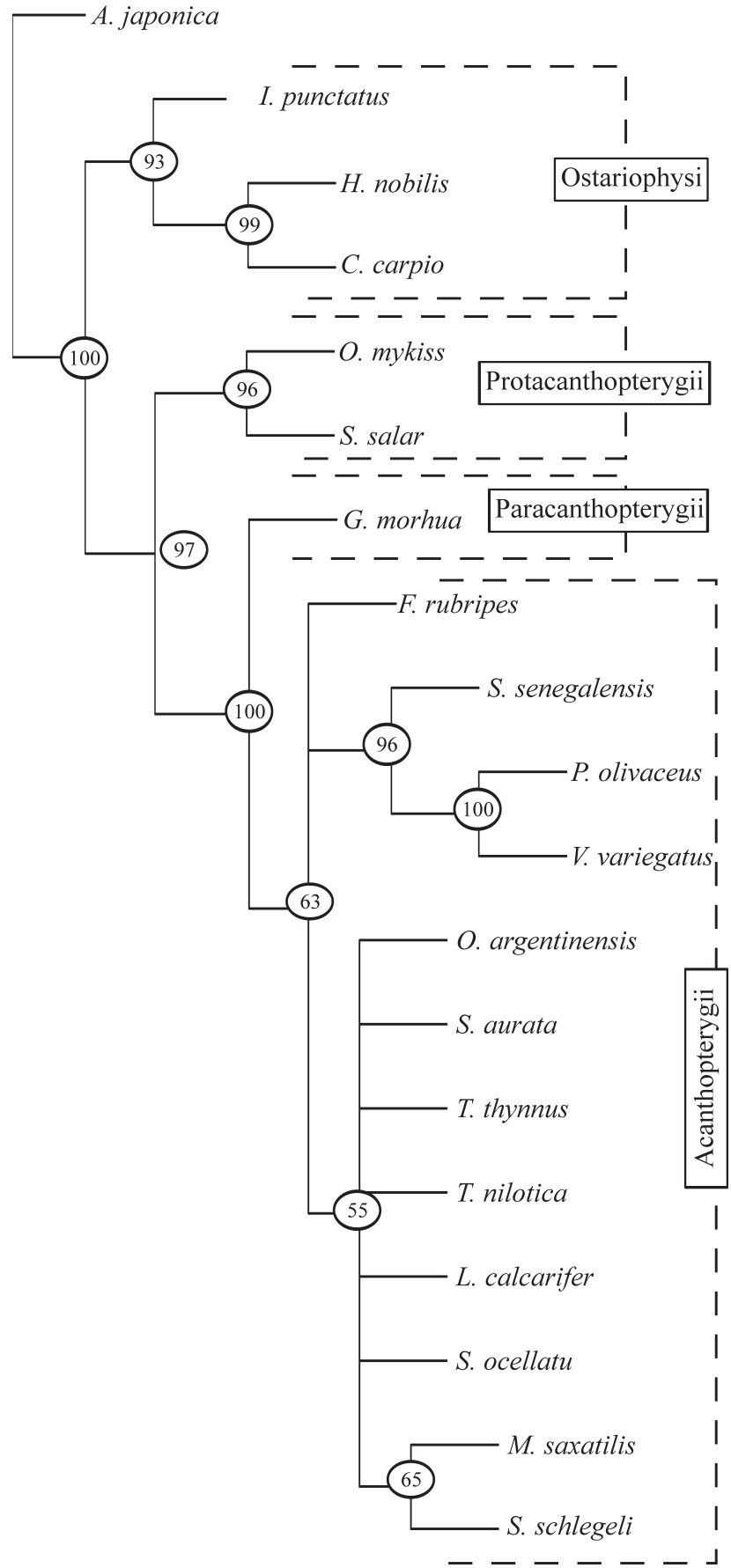

Figure 3 - The strict consensus cladogram (majority rule) of euteleostean GH amino acid sequences using the maximum parsimony method of PHYLIP 3.6. Values at the branch point are the percentage of bootstrap replicates that supported that branch out of 1000 analysis.

ter taxa based in four atherinomorph/mugiloid synapomorphies, even though he made some reservations regarding mugiloids having the percomorph type pelvic girdle which represents a character conflict, suggesting the need for new approaches to solve this question (Stiassny, 1993). Parenti (1993) suggested that atherinomorphs are the sister group of some or all paracanthopterygian fishes. The same author stated that the relationship between atherinomorphs, percomorphs and paracanthopterygians is not resolved because the data are incomplete, arguing that atherinomorphs/percomorphs sister group relationship is barely supported. However, atheriniform fishes were considered to be composed of two monophyletic groups: Atherinopsidae, the New World silversides, and Atherinidae, the Old World silversides both of which have percoids and mugilids as sister-groups (Saeed et al., 1994; Dyer and Chernoff, 1996). Recently, Wiley et al. (2000) in a comprehensive study about the interrelationships of acanthomorph fishes using molecular and morphological data, showed evidence corroborating the Stiassny's (1993) hypothesis that mullets are related to atherinomorphs.

Even though there are many hypotheses for atherinomorphs relationship, our results only allow us to refute the hypothesis that atherinids are related to paracanthopterygians as previously suggested (Parenti, 1993). Within Acanthopterygii we observed a lack of solid synapomorphies among most of the Orders analysed, indicating a complex assemblage of fishes in which the phylogenetic tree remains indeterminable. However, based on the agreement of the molecular data obtained in the present work with the major fish groups currently accepted phylogenies and the more recent approaches using molecular and morphological data, we are sure that nuclear genes such as the growth hormone gene can be useful to solve the question about sister-group relationships in fish. In addition, we would have a better view of this situation if new information at the molecular level was gathered, mainly coming from species representing fish groups that have no such data currently available such as Mugilomorpha (Mugiliformes Order), as well as the remaining Atherinomorpha Orders (Orders Beloniformes and Cyprinodontiformes Orders) and Percomorpha.

\section{Acknowledgments}

The authors are grateful to Professor Norman Maclean for his helpful suggestions and Dr. Olga Francino for fruitful discussions. We also thank Rodrigo Maggioni for technical assistance with cDNA sequencing and Dr. Arati Iyengar for her careful reading of the manuscript. This research was partially supported by IFS (International Foundation for Science, Stockholm, Sweden) through a grant to L.F. Marins (Research Grant Agreement No. A/2915-1), CAPES (Fundação Coordenação de Aperfeiçoamento de Pessoal de Nível Superior, Brazil), CNPq (Conselho Nacional de Desenvolvimento Científico e Tecnológico, Brazil), UAB (Universitat Autònoma de Barcelona, Spain) and FURG (Fundação Universidade Federal do Rio Grande, Brazil).

\section{References}

Beheregaray L and Levy JA (2000) Population genetics of the silverside Odontesthes argentinensis (Teleostei, Atherino- 
psidae): evidence for speciation in an estuary of southern Brazil. Copeia 2:441-447.

Ber R and Daniel V (1993) Sequence analysis suggests a recent duplication of the growth hormone-encoding gene in Tilapia nilotica. Gene 125:143-150.

Bernardi G, D'Onofrio G, Caccio S and Bernardi G (1993) Molecular phylogeny of bony fishes, based on the amino acid sequence of the growth hormone. J Mol Evol 37:644-649.

Dyer BS and Chernoff B (1996) Phylogenetic relationships among atheriniform fishes (Teleostei: Atherinomorpha). Zool J Linn Soc 117:1-69.

Felsenstein J (1985) Confidence limits on phylogenies: an approach using the bootstrap. Evolution 39:783-791.

Felsenstein J (1993) PHYLIP (Phylogeny Inference Package) version $3.5 \mathrm{c}$. Distributed by the author. Department of Genetics, University of Washington, Seattle, M.A.

Frohman MA, Dush MK and Martin GR (1988) Rapid production of full-length cDNA from rare transcripts: amplification using a single gene-specific oligonucleotide primer. Proc Natl Acad Sci USA 85:8998-9002.

Funkenstein B, Chen TT, Powers DA and Cavari B (1991) Cloning and sequencing of the gilthead seabream (Sparus aurata) growth hormone-encoding cDNA. Gene 103:243247.

Gosline WA (1971) Functional morphology and classification of teleostean fishes. University Press of Hawaii, Honolulu.

Johansen B, Johnsen OC and Valla S (1989) The complete nucleotide sequence of the growth-hormone gene from Atlantic salmon (Salmo salar ). Gene 77:317-324.

Kawauchi H and Yasuda A (1989) Evolutionary aspects of growth hormone from nonmammalian species. In: Muller et al., (eds)Advances in growth hormones and growth factor research. Pythagora Press, Rome/Milan and Spring-Verlag, Berlin, pp 51-68.

Koren Y, Sarid S, Ber R and Danie, V (1989) Carp growth hormone: molecular cloning and sequencing of cDNA. Gene 77:309-315.

Momota H, Kosugi R, Hiramatsu H, Ohgai H, Hara A and Ishioka $\mathrm{H}$ (1988) Amino acid sequence of flounder growth hormone deduced from a cDNA sequence. Nucleic Acid Res $16: 10362$

Nelson JS (1994) Fishes of the world. Wiley, New York.

Parenti LR, (1993) Relationships of atherinomorph fishes (Teleostei). Bull Mar Sci 52:170-196.

Rand-Weaver M, Noso T and Kawauchi H (1991) The complete amino acid sequences of two variants of growth hormone from Atlantic cod (Gadus morhua). Gen Comp Endocrinol 81:39-50.

Rentier-Delrue F, Swennen D, Mercier L, Lion M, Benrubi O and Martial JA (1989) Molecular cloning and characterization of two forms of trout growth hormone cDNA: expression and secretion of tGH-II by Escherichia coli. DNA 8:109-117.

Rosen DE (1964) The relationships and taxonomic position of the halfbeaks, killifishes, silversides and their relatives. Bull Amer Mus Nat His 127:217-268.

Rubin DA and Dores RM (1994) Cloning of a growth hormone from a primitive bony fish and its phylogenetic relationship. Gen Comp Endocrinol 95:71-83.

Rubin DA and Dores RM (1995) Obtaining a more resolute teleost growth hormone phylogeny by the introduction of gaps in sequence alignment. Mol Phylogenet Evol 4:129-138.

Saeed B, Ivantsoff W and Crowley LELM (1994) Systematic relationships of atheriniform families within division I of the Series Atherinomorpha (Acanthopterygii) with relevant historical perspectives. J Ichthyol (USSR) 34:27-72.

Saito A, Sekine S, Komatsu Y, Sato M, Hirano T and Itoh S (1988) Molecular cloning of eel growth hormone cDNA and its expression in Escherichia coli. Gene 73:545-551.

Sato N, Watanabe K, Murata K, Sakaguchi M, Kariya Y, Kimura S, Nonaka M and Kimura A (1988) Molecular cloning and nucleotide sequence of tuna growth hormone cDNA. Biochim Biophys Acta 949:35-42.

Stiassny MLJ (1990) Notes on the anatomy and relationships of the bedotiid fishes of Madagascar, with a taxonomic revision of the genus Rheocles (Atherinomorpha: Bedotiidae). Amer Mus Novit 2979:1-33.

Stiassny MLJ (1993) What are grey mullets? Bull Mar Sci $52: 197-219$

Thompson JD, Gibson TJ, Plewniak F, Jeanmougin F and Higgins DG (1997) The ClustalX windows interface: flexible strategies for multiple sequence alignment aided by quality analysis tools. Nucleic Acids Res 24:4876-4882.

Venkatesh B and Brenner S (1997) Genomic structure and sequence of the pufferfish (Fugu rubripes) growth hormoneencoding gene: a comparative analysis of teleost growth hormone genes. Gene 187:211-215.

Wallis M (1996) The molecular evolution of vertebrate growth hormones: a pattern of near-stasis interrupted by sustained bursts of rapid change. J Mol Evol 43:93-100.

Wiley EO, Johnson GD and Dimmick WW (2000) The interrelationships of acanthomorph fishes: a total evidence approach using molecular and morphological data. Biochem. Syst Ecol 28:319-350.

Editor: Fausto Foresti 